\title{
KATEKESE MELALUI MEDIA SOSIAL; MUNGKINKAH?
}

\author{
Oleh: Wilfrid F. Beo Dey dan Mariani P. Daro
}

Abstraksi:
evolusi media sosial yang berbasis internet dan smartphone merambah aneka bidang kehidupan dan amat
mengagumkan. Dunia seolah ada dalam genggaman. Komunikasi sosial menjadi lebih efektif dan
efisien. Katekese sebagai komunikasi iman melihat revolusi media sosial sebagai media alternatif dalam kegiatan pewartaan iman akan Yesus Kristus. Evangelisasi dalam dunia modern mesti memanfaatkan kecanggihan dan kedigdayaan sarana komunikasi massa yang tak tersekat oleh jarak dan tak terbendung oleh waktu. Kehadiran media sosial seperti facebook, twitter, chat, dan instagram baik yang berbasis internet maupun smartphone membantu pewartaan iman sehingga semakin hidup karena memiliki sifat dialogisresiprokal. Tulisan ini mengajak pembaca untuk menemukan peluang alternatif dalam berkatekese melalui media sosial.

Kata kunci: Katekese, pewartaan iman, media sosial, komunikasi iman.

\section{Catatan Awal}

Perkembangan media komunikasi sosial maju pesat. Media komunikasi sosial telah memangkas jarak, menumbuhkan efisiensi dan efektivitas yang mengagumkan. Komunikasi antarmanusia menjadi sangat efisien karena waktu yang dibutuhkan sangat sedikit untuk berhubungan dengan orang lain. Efektivitasnya juga terjamin sebab pesan yang disampaikan bisa langsung diterima komunikan dengan sedikit sekali kemungkinan distorsi. Penggunaan media komunikasi sosial telah menjadi kebutuhan dan tidak lagi hanya sekedar untuk kesenangan dan hiburan. Media komunikasi sosial (selanjutnya disebut: media social atau disingkat medsos) hadir melalui revolusi teknologi komunikasi berbasis digital seperti komputer, laptop dan smartphone dengan fitur-fitur atau aplikasi canggih dan memungkinkan orang untuk semakin banyak pilihan dalam penggunaannya. Di antara pelbagai aplikasi yang ada, beberapa yang paling populer bisa disebut di sini seperti email, facebook, twiter, whats-up (WA), line, path. Beberapa media sosial ini menyapa penggunanya hanya dengan pemanfaatan jaringan internet atau penggunaan smartphone. Luasnya jaringan internet dan berlipatgandanya pengguna smartphone menjadikan komunikasi lebih gampang dilaksanakan, informasi lebih cepat diakses.

Bagi yang berpikiran positif, kemudahan-kemudahan yang ditawarkan media sosial adalah peluangpeluang baru yang harus dimanfaatkan untuk perkembangan hidup manusia termasuk dalam hal pewartaan iman dan ajaran agama. Kehadiran media sosial menjadi peluang emas untuk memikirkan terobosan baru dalam pola pengajaran iman termasuk di dalamnya iman Katolik. Katekese konvensional yang selama ini telah dipraktikan dalam kehidupan umat perlu mendapat sentuhan baru dengan memanfaatkan kecanggihan media sosial yang bisa menjangkau sesama umat Katolik secara lebih luas dan cepat. Bahkan, media sosial dapat menyebarkan sabda Tuhan hingga wilayah yang tak terjangkau dan untuk jumlah manusia yang tak terbatas. Evangelii Nuantiandi menyatakan bahwa gereja berdosa di hadapan Allah apabila tidak menggunakan sarana ini.

Dari latar berpikir di atas maka penulis mencoba melihat peluang pada media sosial sebagai ruang publik baru yang bisa dimanfaatkan sebagai alternatif bagi pola pewartaan ajaran iman Kristen. Karena itu tema yang mau didalami dalam karya tulis ini adalah: “berkatekese melalui media sosial; mungkinkah?”. Ini sebuah 
kajian spekulatif yang mencoba melihat peluang sekalian tantangan yang perlu bagi kegiatan katekese yang memanfaatkan media sosial.

\section{Kehadiran Media Sosial yang Mengagumkan}

Kehadiran jaringan internet yang terhubung ke personal computer (PC) menjadi cikal bakal munculnya aneka media sosial yang berguna bagi manusia. Di sisi lain, inovasi dalam tekhnologi telepon seluler (HP) dengan kehadiran beranekaragam smartphone atau perangkat telepon pintar semakin menambah semarak karena media sosial tidak lagi diakses hanya melalui komputer portable tetapi sudah dalam genggaman (baca: smartphone) dan semakin mempribadi. Menurut Kamus Umum Bahasa Indonesia, internet adalah jaringan elektronik yang menghubungkan jaringan komputer dan fasilitas komputer yang terorganisasi di seluruh dunia melalui telepon atau satelit (KUBI, 2008: 543). Internet dengan jaringan terluas ini, menghubungkan berbagai bentuk komputer dengan macam-macam layanannya yang pada umumnya dapat mempermudah individu pengguna untuk mengakses berbagai informasi di seluruh negara yang terjaring ke-internet-an.

Kehadirian jaringan internet melahirkan beragam kelompok aplikasi yang memudahkan manusia terhubung satu dengan yang lain lewat media-media sosial. Media sosial adalah sebuah media online, yang penggunanya bisa dengan mudah berpartisipasi, berbagi, dan menciptakan isi (content) yang meliputi blok, jejaring sosial, wiki, forum dan dunia virtual. Blog, jejaring social, dan wiki merupakan bentuk media sosial yang paling umum digunakan oleh masyarakat di seluruh dunia. Pendapat lain mengatakan bahwa media sosial adalah media online, yang mendukung interaksi sosial dan media sosial tersebut menggunakan teknologi berbasis web yang mengubah komunikasi menjadi dialog interaktif.

Andreas Kaplan dan Michael Haenlein mendefensisikan media sosial sebagai kelompok aplikasi berbasis internet yang dibangun atas dasar ideologi dan tekhnologi web 2.0 dan yang memungkinkan penciptaan dan pertukaran user-generated content. Jejaring sosial merupakan situs di mana setiap orang bisa membuat web page pribadi, kemudian terhubung dengan teman-teman untuk berkomunikasi dan berbagi informasi. Jejaring sosial terbesar adalah facebook, Myspace, twitter, instagram, dan chat. Jika media tradisional menggunakan media cetak dan broadcast, maka media sosial menggunakan internet. Media sosial mengajak siapa saja yang tertarik untuk bergabung, memberi kontribusi dan feedback secara terbuka, beri komentar, berbagi informasi dalam waktu yang cepat dan tak terbatas.

Saat teknologi internet dan smartphone makin maju maka media sosial ikut tumbuh dengan pesat. Kini untuk mengakses facebook atau twitter misalnya, bisa dilakukan dimana saja dan kapan saja hanya dengan sebuah smartphone. Seorang pengguna media sosial bisa mengakses dengan jaringan internet bahkan yang aksesnya lambat sekalipun, tanpa biaya besar, tanpa alat mahal, dan dilakukan sendiri tanpa harus kuliah IT. Kita sebagai pengguna media sosial bisa dengan bebas mengedit, menambahkan, memodifikasi baik tulisan maupun gambar, video, grafis, dan pelbagai model content lainnya.

Ciri-ciri media sosial dapat dikemukakan di sini yakni; pertama, pesan yang disampaikan tidak hanya untuk satu orang saja, namun bisa kepada banyak orang. Kedua, pesan yang disampaikan bebas, tanpa harus melalui suatu gatekeeper. Ketiga, pesan yang disampaikan cenderung lebih cepat ketimbang media lainnya. Keempat, penerima pesan yang menentukan kualitas interaksi. Berdasarkan ciri-ciri di atas, media sosial memiliki keunggulan-keunggulan berikut: Pertama, sederhana. Media sosial tidak butuh keterampilan tingkat tinggi seperti pada media konvensional lainnya namun hanya membutuhkan komputer dan koneksi internet. Kedua, membangun hubungan. Media konvensional mempraktikan komunikasi satu arah sedangkan media sosial berfungsi membangun hubungan karena bisa langsung dapat feedback, ide, pengujian dan mengelola layanan pelanggan dengan cepat. Ketiga, jaringan global. Media sosial memungkinkan menyesuaikan content 
untuk segmen pasar tertentu dan kesempatan bisnis untuk mengirim pesan kepada lebih banyak pengguna. Keempat, terukur. Pengiriman pesan dapat terukur sehingga pengirim pesan dapat dengan mudah mengetahui efektivitas dari sebuah pesan dan seberapa banyak orang yang mengakses pesan tersebut (https://ptkkomunikasi.wordpress.com).

Keberadaan internet dan smartphone telah dilengkapi dengan fitur-fitur media sosial sangat mengagumkan. Menilik kembali ke masa lampau, manusia harus menunggu dalam jangka waktu yang cukup lama untuk mendapatkan informasi. Informasi tersebut bahkan didapat setelah menjadi basi. Pada masa lampau komunikasi terkendala jarak dan teknologi yang masih minim. Hal ini menyebabkan problematika dalam efisiensi dan efektivitas.Tapi kini semua telah berubah, tak berlebihan kalo dikatakan dalam hitungan sepersekian detik informasi atau pesan yang termediasi oleh media sosial menyebar cepat. Bahkan terlalu banyak informasi yang masuk menyebabkan era ini disebut sebagai era dimana manusia kebanjiran informasi. Manusia mesti punya kecakapan untuk bersikap selektif dalam menerima informasi atau pesan karena bisa saja manusia dibohongi oleh informasi-informasi yang disebar oleh orang yang memanfaatkan kelemahan media sosial.

Dengan demikian keberadaan internet dan beragam aplikasi yang menggunakan jasa internet boleh dikatakan sangat mengagumkan. Orang bisa memanfaatkannya untuk kepentingan dan kebaikan banyak orang, kendati di sisi lain ada dampak negatif sebab tidak sedikit pula kejahatan yang memanfaatkan media sosial (cyber crime). Tetapi fokus pembahasan ini hanya pada dampak positip media sosial bagi kemanusiaan. Kita harus jujur bahwa banyak orang merasa beruntung dengan kehadiran media sosial.

\section{Media Sosial: Budaya Media yang Tak Bisa Dihindari}

Media sosial telah menjadi budaya komunikasi baru dalam kehidupan. Media sosial hadir sebagai budaya alternatif di tengah budaya media konvensional yang memiliki kekurangan. Kehadiran media sosial dengan kelebihannya seakan untuk mengisi kekurangan atau kelemahan media komunikasi konvensional seperti media cetak dan broadcast. Keadaan ini merefleksikan sebuah pemahaman dan praktik bermedia yang pada gilirannya membentuk sebuah kesadaran tentang budaya media baru yang sulit untuk dihindari.

Budaya media adalah istilah yang dipergunakan untuk menjelaskan satu fenomena tertentu dalam perkembangan teknologi komunikasi. Fenomena ini menunjukkan bahwa media komunikasi modern dilihat telah mampu menghasilkan produk-produk teknologi hiburan dan informasi yang mampu menciptakan perubahan-perubahan tertentu baik dalam lingkup personal maupun dalam lingkup sosial. Budaya media dicirikan sebagai budaya gambar dan suara yang mengambil bentuk dalam produk hiburan, informasi, persuasi, dan edukasi yang didesain khusus untuk memiliki nilai pasar yang tinggi. Budaya media sebagai produk teknologi komunikasi modern diproduksi sekian untuk menjawabi tujuan dasar komunikasi, yaitu lahirnya suatu perubahan, baik pada level sikap dan tindakan seseorang maupun pada level sosial (Lukas Batmomolin, 2003:39-41). Dengan demikian media sosial yang terkoneksi dengan jaringan internet dan juga smartphone telah tumbuh menjadi gaya hidup baru yang kemudian amat tepat dikatakan sebagai budaya media yang mempesona, mengagumkan dan sulit untuk dihindari dan dikontrol.

\section{Media Sosial sebagai Sarana Alternatif Berkatekese}

Suatu hari yang cerah, tanpa sengaja Penulis membuka dan membaca sms-sms yang tersimpan di draft kotak masuk dalam handpone milik adik perempuan. Memang ada beberapa sms berasal dari rekan kerjanya, perihal kabar dan urusan pekerjaan. Namun hampir sebagian besar sms yang ada dalam draft kotak masuk berisikan sejumlah renungan harian, lengkap dengan bacaan Kitab Suci dan pertanyaan refleksinya. Penulis lalu 
bergumam dalam hati, "Luar biasa, seorang bidan dengan latar belakang pendidikan kesehatan dan jadwal pekerjaan yang padat, masih menyempatkan diri sejenak membaca dan merenungkan Sabda Tuhan. Sementara penulis sebagai seorang katekis yang hampir tiap hari bergelut dalam bidang kerohanian, tidak ada satu sms pun yang berisikan "renungan" atau firman Tuhan, baik harian maupun yang lainnya."

Ilustrasi singkat di atas mau menggambarkan betapa pentingnya peran media sosial bagi pewartaan Sabda Tuhan. Menurut pengamatan dan pengalaman penulis, setiap orang tanpa disadari selalu berusaha mencari dan memperoleh informasi mengenai Sabda Tuhan melalui berbagai sumber. Faktor kesibukan akan pekerjaan dan aktivitas hidup lainnya membuat orang tak memiliki kesempatan untuk sejenak membaca dan merenungkan firman Tuhan. Hal inilah yang menuntut seseorang untuk 'mencari keselamatan' lewat media alternatif, yakni media sosial dengan sajian bacaan Kitab Suci, renungan, cerita dan gambar rohani. Mereka kerapkali menggunakan media-media sosial yang sesuai dengan perkembangan zaman dan lebih canggih. Media yang sering digunakan adalah facebook, twitter, chat, instagram, dan lain-lain. Tidak heran jika kesempatan untuk memperoleh "Firman Tuhan" selalu ada karena memang didukung oleh fasilitas yang cukup memadai tersebut.

Media sosial telah menjadi kebutuhan penting bagi sebagian manusia zaman ini. Media sosial bahkan menjadi kebutuhan harian sebagian manusia dewasa ini karena telah menjadi sarana alternatif untuk memberi atau mendapatkan informasi, hiburan, bisnis, dan edukasi. Bahkan orang merasa bingung dan kehilangan, bila dia tidak memiliki akses kepada media sosial. Dengan perubahan yang begitu cepat dalam aneka perniknya, media sosial semakin menggoda manusia, bahkan membentuk sejenis ketergantungan yang tumbuh dan berkembang secara meluas, khususnya di kalangan kaum muda. Inilah bagian dari gaya hidup semasa, khususnya dalam menciptakan jejaring sosial sebagai bentuk "pengakuan dan perwujudan diri” di dalam budaya digital.

Menurut data dari We Are Social, pengguna internet aktif di seluruh dunia kini mencapai 3,17 miliar. Dari tahun ke tahun, jumlah pengguna internet bertumbuh hingga 7,6 persen. Pertumbuhan pengguna internet ini juga berpengaruh terhadap pertumbuhan pengguna media sosial dan mobile. Menurut laporan yang sama, pengguna media sosial aktif kini mencapai 2,2 miliar, sedangkan pengguna mobile phone mencapai 3,7 miliar. Sementara data mengenai pengguna facebook menyatakan bahwa 1 dari 13 orang di dunia saat ini memiliki sebuah akun facebook. Lebih dari separuhnya log in setiap hari, artinya hampir $10 \%$ jumlah seluruh populasi dunia terhubung dalam facebook. Dan setengahnya mengakses facebook setiap hari. Selain itu $2 \%$ dari seluruh pencarian di google tahun 2010 lalu mengandung kata facebook. Facebook diterjemahkan ke dalam 76 kata serta 35 juta orang mengubah status facebook-nya setiap hari. Bisa dibayangkan bagaimana sibuknya 'dunia maya' saat itu dengan berbagai informasi dan tawaran menarik untuk dilihat (http//www.detiknet.com/read/).

Berdasarkan fakta tersebut, tidak dapat dipungkiri bahwa media sosial kini menjadi trend setter sekaligus menjadi sarana paling ampuh untuk melakukan pewartaan (katekese). Media-media seperti facebook, twitter, chat, instagram, dan lain-lain tentunya akan sangat membantu memberikan pengajaran agama atau kabar gembira tentang karya penyelamatan Tuhan. Hal ini merupakan kebanggaan rohani yang luar biasa bila setiap orang mulai memanfaatkan media tersebut bagi pertumbuhan dan perkembangan iman kristiani.

Penulis mengutip kata-kata Kitab Suci yang berbunyi, "Tuhan Yesus datang ke dunia untuk memberi kita hidup, dan mempunyainya dalam kelimpahan (Yoh 10:10). Maka hidup dalam Kristus dengan segala kelimpahannya ini patut diwartakan dan diperjuangkan, juga di era multimedia, dimana kekuatan gambar dan suara perlu diperhitungkan dan dimanfaatkan untuk melengkapi karya pastoral (penggembalaan) tradisional 
sehingga kawanan domba Kristus di zaman modern ini akhirnya bisa menemukan padang berumput hijau (lih. Mzm 23) dan hidup dalam segala kelimpahannya.

Media sosial menjadi sangat penting sebagai sarana pewartaan sesuai dengan perannya dalam Media Komunikasi Sosial Gereja Katolik: Pertama, sebagai sarana evangelisasi. Ungkapan bahwa media massa sebagai salah satu cara untuk evangelisasi dengan jelas terdapat dalam Ensiklik Evangelii Nuntiandi (EN 45). Gereja menempatkan media massa sebagai alat dalam pewartaan Injil; bahwa pesan Injil juga dapat sampai kepada banyak orang berkat kehadiran media massa. Kedua, sebagai sarana pembinaan iman; poin ini menegaskan inti dari penempatan media massa sebagai peluang untuk menyebarkan Kabar Gembira. Proses pemberitaan Injil ini mengarahkan orang kepada semangat untuk mengembangkan iman. Ketiga, sebagai sarana pewartaan iman, cinta kasih dan kebenaran. Ensiklik Evangelii Nuntiandi secara jelas memperlihatkan bahwa evangelisasi melalui sarana-sarana komunikasi adalah penting dalam pewartaan nilai-nilai Injili yakni cinta kasih dan kebenaran (EN 45). Melalui sarana-sarana tersebut Gereja dapat memperkenalkan dan membuka dirinya untuk bersaksi tentang Kristus. Memberikan kesaksian iman dan kebenaran-kebenaran hidup, menunjukkan adanya nilai yang diperjuangkan yaitu; berkaitan dengan motivasi iman. Penggunaan media massa berorientasi pada martabat hidup manusia sebagai nilai tertinggi dan bukan pada kecanggihan teknologi itu sendiri. Gereja perlu menyerukan dan menunjukkan kebenaran melalui media-media tersebut, supaya manusia menyadari akan realitas dunia yang semakin tidak teratur dan tak terkontrolkan. Jadi media massa hanyalah sarana yang membantu pewarta menerangkan isi iman Katolik dan tidak menjadikannya sebagai tujuan.

Selain itu, media massa ternyata juga memainkan peranan penting dalam karya pewartaan. Media massa dapat digunakan untuk mewartakan ajaran-ajaran Kristus, agar ajaran-ajaran Kristus tersebut dapat dikenal dan diterima seutuhnya oleh seluruh manusia di dunia. Akhirnya ajaran-ajaran Kristus itu tidak hanya membawa keselamatan bagi umat beriman kristiani saja, melainkan juga kemajuan bagi seluruh manusia di dunia (Bdk. IM 2). Hal ini dapat kita lihat antara lain pada fakta muncul banyak majalah, program-program televisi dan situs-situs di internet yang bersifat kerohanian yang dapat diakses dengan mudah.

Media komunikasi juga memiliki peran dan jasa besar bagi umat manusia, untuk menyegarkan hati, mengembangkan budi dan untuk menyiarkan serta memantapkan Kerajaan Allah. Semua peran media komunikasi akan terwujud, jika media komunikasi digunakan secara tepat. Untuk itu, setiap orang Katolik memiliki tanggung jawab untuk mewartakan imannya akan Kristus kepada sesama. Dasar pijak pewartaan seorang Kristiani adalah hidup dan karya Yesus Kristus. Setelah dibaptis, ia tidak hanya bersatu dengan Kristus melainkan sekaligus menerima tugas utama yaitu "memberi kesaksian tentang Kristus yang diimaninya". Pewartaan mutlak tidak hanya dilakukan melalui kesaksian hidup dan perbuatan nyata, melainkan kesaksian bisa juga dilakukan dengan 'berbagi motivasi iman' melalui sarana-sarana yang menunjang dan tentunya bermanfaat bagi banyak orang. Pewartaan melalui media sosial sebagai salah satu media komunikasi masa, secara tidak langsung dapat mempengaruhi dan mengundang orang lain untuk turut serta menjadi pewarta. Menjadi pewarta berarti ikut ambil bagian dalam karya penyelamatan Kristus sehinga setiap orang Kristen dipanggil untuk menjadi saksi Yesus Kristus dan Injilnya.

Tentang media komunikasi sosial ini juga dipertegas oleh Konferensi Waligereja Indonesia ketika mengatakan bahwa evangelisasi budaya modern bergantung pada berapa besarnya pengaruh media. Suatu penghargaan yang besar bagi media karena mutu komunikasinya yang istimewa. Dengan demikian orang dapat menilai apa yang telah mereka terima dari media secara pribadi dan mendalam (KWI, 2000: 182-183). Secara singkat sarana harus berkaitan dengan kehidupan nyata dari generasi yang menerima katekese, memperlihatkan pengenalan yang akrab dengan kegelisahan dan masalah-masalah, perjuangan-perjuangan dan harapan- 
harapannya. Berusaha berbicara kepada generasi dengan penuh arti. Sungguh-sungguh bermaksud memberikan kepada mereka yang memakainya suatu pengetahuan yang lebih baik tentang misteri Kristus, agar mencapai pertobatan yang sejati dan hidup yang lebih sesuai dengan kehendak Allah.

Katekese melalui media sosial harus dimengerti sebagai kesempatan memberi kesaksian, bukan karena orang di luar Gereja dikhawatirkan masuk neraka, melainkan karena suatu berita gembira jangan ditutup-tutupi sambil tetap menghormati otonomi orang lain. Bagaimana ia bereaksi, apakah ia percaya atau tidak, bahkan apakah ia memperhatikan atau tidak, semua ditentukannya sendiri. Kebebasan dan keutuhan orang sepenuhnya dihormati. Kesaksian diberikan dengan tenang dan dalam kesadaran bahwa semuanya di tangan Tuhan. Adalah Tuhan yang mengubah hati orang. Adalah Tuhan juga yang mengizinkan bumi ini dihuni oleh orang dari agama berbeda (Suseno, 2004: 37-38).

Dengan demikian, katekese melalui media sosial dapat mendidik orang untuk menjadi beriman sehingga suasana iman itu dirasakan, bertumbuh, dan berbuah dalam setiap sanubari. Selain itu katekese menolong umat terpikat pada diri Allah yang diwartakan Yesus Kristus, sehingga terdorong untuk melakukan kehendak dan perintah Allah (Telaumbanua, 1999: 9). Maka ada baiknya pewartaan atau katekese melalui media sosial digalakkan sejak saat ini sampai kapanpun karena iman umat harus tetap tumbuh di zaman modern. Term "di sini dan sekarang ini" menyiratkan sebuah pemahaman bahwa media berkatekese harus selaras dengan konteks saat ini dan tidak dapat ditunda. Ini berarti penggunaan media sosial dalam berkatekese harus dilakukan saat ini. Ini merupakan agenda mendesak yang harus dilaksanakan.

Melihat pentingnya pewartaan iman bagi sesama, maka orang kristiani mesti tergerak hatinya untuk berlomba-lomba memberikan kesaksian imannya akan Kristus. Media sosial menjadi sarana paling efektif untuk membantu karya pewartaan di zaman ini. Namun, syaratnya mesti menguasai teknologi dan memanfaatkan media-media tersebut dengan baik dan benar sesuai dengan kebutuhan pewartaan. Maka perlu ada inovasi dalam berkatekese melalui media sosial.

\section{Inovasi Teknik Berkatekese Melalui Media Sosial}

Berbicara mengenai teknik, tentu orang akan terarah pada cara-cara yang digunakan untuk suatu tujuan. Di sini penulis akan secara rinci membahas tentang cara baru berkatekese melalui media sosial yang saat ini sedang booming di tengah masyarakat. Mengapa penulis katakan demikian karena hampir sebagian besar orang mengenal, menggunakan bahkan menjadikan media sosial sebagai kebutuhan pribadi untuk sekedar mencari informasi, melakukan jual beli online, men-download lagu, gambar, data, mengirim dan menerima email, membuat dan membaca status, dan lain sebagainya. Kebiasaan-kebiasaan ini sudah merupakan fenomena yang berkembang pesat dari masa ke masa dan kemungkinan akan terus bertumbuh, bergejolak dan memengaruhi seluruh aktivitas hidup setiap orang. Fenomena yang terjadi bukan hanya di daerah perkotaan, sebut saja di kota besar seperti Jakarta, atau kota kecil seperti Ende. Namun di daerah-daerah pedesaan seperti Detusoko, Maurole, Moni, Wolotopo, dan daerah lainnya di Kabupaten Ende, orang sudah menjadikan gadget atau smartphone sebagai kebutuhan harian.

Setiap orang Katolik yang memiliki akses ke media sosial tertentu bisa berkatekese melalui media sosial dan tentu saja bermanfaat juga untuk mempengaruhi orang lain membagikan apa yang sudah ditulis itu kepada orang lain. Media-media yang ditekankan di sini adalah facebook, twitter, chat, dan instagram. Secara tekhnis beberapa hal perlu dilakukan, yakni: pertama,orang mesti memiliki email dan password yang terdaftar. Misalnya: Patrixia-daro@ yahoo.co.id. Kemudian bisa mendaftar di masing-masing pilihan media sosial seperti facebook, twitter, instagram, chat, dan lain-lain. Kedua, dalam facebook atau twitter yang sudah ada, silahkan 
men-share dan menceritakan bagaimana Kristus hidup dalam kejadian sehari-hari, serta bagaimana merefleksikan bacaan Kitab Suci dalam kehidupan sehari-hari. Lihat contoh twitter dari Vatikan.

Teknik selanjutnya yang bisa dilakukan seorang pewarta di sosial media ialah mewartakan dengan cerita. Cerita-cerita ditampilkan lewat video, dibagikan lewat akun facebook, twitter, chat dan instagram. Hal ini membantu orang dapat mengetahui dan mengingat kembali teladan-teladan para kudus, misalnya film santosanta, film para nabi, film Tuhan Yesus menurut keempat Injil atau film tentang kehidupan para rahib. Ceritacerita di dalam film ini menyuguhkan nilai-nilai iman dan teladan kehidupan yang dapat sangat berdampak bagi perkembangan iman, serta membantu pewartaan iman.

Pewartaan iman bisa dilakukan melalui gambar. Dengan menggunakan gambar-gambar yang di-upload ke media sosial seperti gambar-gambar kudus. Melalui gambar-gambar ini seorang pewarta dapat membawa umat untuk berefleksi tentang cara hidup para kudus. Melalui refleksi gambar, umat diajak untuk merenung, mengenang dan menghadirkan kembali sosok orang kudus ke dalam kehidupan sekarang. Kemudian umat diajak untuk berdevosi kepada para kudus karena keyakinan bahwa mereka dekat dengan Tuhan dan menjadi pengantara rahmat-Nya. Dengan demikian, pemanfaatan media sosial sungguh dapat membantu kegiatan pewartaan iman di zaman teknologi seperti sekarang ini.

Keuntungan yang diperoleh apabila berkatekese melalui media sosial, yakni apa yang dibagikan akan mendapat umpan balik (feedback), tanggapan dari orang lain berupa like, atau balasan berupa komentar. Hal ini menunjukkan dengan sangat benderang bahwa melalui media sosial komunikasi iman menjadi lebih hidup. Pewarta tidak menjadi subjek dan followers hanya menjadi objek pewartaan yang pasif melainkan akan terjalin suatu relasi timbal-balik yang egaliter antara pewarta dan penerima warta (followers). Komunikasi iman yang terjalin akan menjadi lebih dialogal karena memungkinkan partisipasi aktif, resiprokal antara sesama subjek yang aktif dalam pewartaan Injil. Keuntungan lain dari penggunaan media sosial dalam pewartaan adalah tampilannya menarik, merangsang minat orang untuk membaca dengan tawaran aplikasi-aplikasi yang mengagumkan. Tidak heran jika mata para followers akan terus terbuka dan menatap bahkan tidak berhenti membaca setiap tulisan (baca: status) di media sosial.

Hal lain yang tak kalah pentingnya dalam penggunaan media sosial ialah pewarta sebaiknya belajar sungguh-sungguh bagaimana memanfaatkan media dengan tepat. Karena sebagai sarana pewartaan iman, media sosial juga harus mempunyai cara-cara bagaimana membuat suatu pewartaan menjadi menarik. Gereja melihat dengan jeli peluang-peluang yang disediakan internet untuk pewartaan atau karya evangelisasi. Dalam dokumen Ethics in Internet No.3 dikatakan bahwa:

Internet dapat membantu masyarakat mewujudkan tanggung jawab mereka atas kebebasan dan demokrasi, memperluas ruang lingkup pilihan yang tersedia dalam arena kehidupan berbeda, mengedepankan kemajuan manusia dalam segala aspek, mendorong kesejahteraan, perdamaian, pertumbuhan intelektual dan kebudayaan. Sikap saling pengertian antar-masyarakat dan bangsa serta mendorong dialog antar-agama yang kelak menjadi sarana perwujudan peradaban cinta kasih.

Hal ini dengan jelas menunjukkan bahwa Gereja tetap melihat nilai positif penggunaan internet dan kekayaan aplikasinya sebagai sarana pewartaan, pendalaman Kitab Suci, pendidikan iman umat, pembimbingan rohani, pengembangan hidup sosial, dan kesejahteraan masyarakat.

Itulah beberapa teknik atau cara berkatekese melalui media sosial yang sudah mulai digunakan dalam pewartaan iman. Siapapun yang terlibat dalam pewartaan di zaman ini, tak berlebihan jika dikatakan sulit untuk menghindar dari cara mewartakan melalui media sosial. Setiap pewarta iman perlu didorong untuk mendukung 
dan memanfaatkan pewartaan iman melalui media sosial. Karena itu, semua yang telah memanfaatkan kecanggihan media sosial diajak untuk terlibat aktif menjadi 'penyaksi Kristus' di era digital. Tetapi, pewartaan melalui media sosial, bukan satu-satunya cara pewartaan iman, melainkan hanya salah satu sarana alternatif yang sesuai dengan tuntutan zaman. Umat mesti sadar betul bahwa kesaksian hiduplah yang paling utama dengan berpedoman pada Kitab Suci sebagai inspirasi iman.

\section{Catatan Akhir}

Paus Yohanes Paulus II dalam pesannya untuk hari komunikasi sedunia tahun 2002 memberikan semacam testimoni yang mengagumkan terhadap internet dan seluruh aplikasi yang menjadi kekayaan internet termasuk di dalamnya media-media sosial. Ia mengatakan bahwa:

Gereja menyikapi media baru ini dengan sikap realistis dan percaya diri. Seperti media lainnya, media baru ini adalah sarana, bukan tujuan dalam dirinya sendiri. Internet mampu menyediakan peluang-peluang yang bagus sekali untuk evangelisasi, bila digunakan dengan kecakapan dan kesadaran yang jelas akan berbagai kekuatan dan kelemahannya (Duka, 2005:189).

Media sosial telah mengubah paradigma komunikasi sosial dalam Gereja. Komunikasi satu arah antara pewarta dan penerima warta telah perlahan diubah menjadi komunikasi timbal balik (resiprokal). Ada suasana dialogis di dalamnya yang memungkinkan orang kristen untuk mengalami Allah yang pada dasarnya dialogis. Hal ini berpengaruh pula pada pewartaan iman Kristen. Cara-cara pewartaan iman konvensional telah perlahanlahan mendapat sentuhan baru melalui media sosial. Artinya media sosial telah menjadi media alternatif dalam pewartaan iman Kristen.

Keunggulan-keunggulan pada media sosial seperti kecepatan mengirim pesan dan daya jangkau yang tak terbatas menyebabkan efektivitas dan efisiensi mendapat tempat istimewa dalam komunikasi. Tuntutan bagi para pengajar dan penyaksi iman adalah secara kreatif memanfaatkan keunggulan media sosial secara cerdas untuk mewartakan Kristus kepada segala bangsa.

\section{Daftar Rujukan:}

\section{Dokumen dan Kamus}

Kamus Besar Bahasa Indonesia. 2008. Penerbit Gramedia Pustaka Utama, Jakarta.

Konsili Vatikan II. 1993. Dekrit Tentang Upaya-Upaya Komunikasi Sosial, Inter Mirifica, no. 2, dalam Dokumen Konsili Vatikan II, R. Hardawirjana, SJ (penerj.). Obor, Jakarta.

Paulus VI. 1990. Ensiklik Evangelii Nuntiandi. DOKPEN KWI, Jakarta.

\section{Buku-buku}

Batmomolin, Lukas dan Fransisca Hermawan. 2003. Budaya Media. Nusa Indah, Ende.

Duka, Agus Alfons (ed.). 2007. Voice in the Wilderness, Ledalero, Maumere.

Konferensi Waligereja Indonesia. 2002. Pewartaan Kristiani. Kanisius, Yogyakarta. 
Supardi, Yuniari, Internet Untuk Segala Kebutuhan.2009. Penerbit PT. Elex Media Komputindo, Jakarta.

Suseno, Franz Magnis. 1999. Menjadi Saksi Kristus. Kanisius, Yogyakarta.

Telaumbanua. 1999. Ilmu Kateketik: Hakikat dan Metode. Obor, Jakarta.

\section{Situs Internet}

https://ptkkomunikasi.wordpress.com, diakses tanggal 26 November 2015.

http//www.detiknet.com/read, diakses tanggal 28 November 2015. 